\title{
PELATIHAN PENYUSUNAN RPP BERMUATAN PENDIDIKAN KARAKTER PADA GURU-GURU DI SEKOLAH DASAR NOMOR 1 KAPAL
}

\author{
oleh, \\ I Gede Nurjaya \\ Fakultas Bahasa dan Seni \\ Universitas Pendidikan Ganesha
}

\begin{abstract}
ABSTRAK
Kegiatan pengabdian masyarakat ini bertujuan untuk meningkatkan kemampuan guruguru di SD Nomor 1 Kapal Badung dalam menyusun RPP bermuatan karakter yang terarah dan sistematis, melalui pelatihan. Pelaksanaan pelatihan dibagi menjadi 3 sesi yaitu sesi pertama pemaparan tentang hakikat RPP dan pendidikan karakter, dilanjutkan tanya jawab, dan kedua pendampingan latihan menyusun RPP, dan sesi ketiga berupa implementasi RPP pada pembelajaran di kelas. Hasil yang ditemukan adalah (1) peserta pelatihan sangat antusias mengikuti pelatihan, (2) rata-rata skor penyusunan RPP oleh guru SDN 1 Kapal adalah 32,5 ( $\Sigma \mathrm{N}=40)$ setara dengan nilai 81 pada skala 100 , (3) sebagian besar peserta pelatihan $(80 \%)$ berhasil menyusun sebuah RPP bermuatan pendidikan karakter.
\end{abstract}

Kata-kata kunci : RPP, standar proses, pendidikan karakter

\begin{abstract}
The community service aimed to improve the ability of teachers in elementary No. 1 Kapal Badung in preparing lesson plans based on character education systematically, through training. The training was divided into three sessions: the first session presentation on the nature and character education lesson plans, followed a question and answer, and both mentoring practice in preparing lesson plans, and the third session in the form of implementation of the RPP on learning in the classroom. The results were (1) participants were keen to follow the training, (2) the average score of the preparation of lesson plans by the teacher SDN 1 ship is $32.5(\Sigma \mathrm{N}=40)$ is equivalent to the value of 81 on a scale of $100,(3)$ most of the trainees $(80 \%)$ managed to put together a lesson plan based on character education.
\end{abstract}

Keywords: lesson plan, standard processes, character education

\section{Pendahuluan}

Sampai saat ini, perencanaan dan implementasi pembelajaran di sekolah tampaknya belum mengarah pada pembentukan kompetensi siswa secara utuh. Hal ini 
dapat dilihat dari hasil studi yang dilakukan Pusat Kurikulum Depdiknas yang menyatakan bahwa (1) sebagian besar siswa tidak mampu mengaplikaksikan konsepkonsep sains dalam kehidupan nyata dan (2) pengajaran tidak menitikberatkan pada prinsip bahwa sains mencakup pemahaman konsep, dan menghubungkannya dengan kehidupan sehari-hari. Hal senada juga ditemukan pada studi Suastra, dkk (2006) yang menyatakan bahwa metode ceramah masih mendominasi kegiatan belajar dalam pembelajaran di sekolah, sedangkan metode demonstrasi dan eksperimen hampir tidak mendapat perhatian serius. Kualitas metode ceramahpun juga mengalami kemerosotan, siswa tidak lagi mendengarkan dengan seksama penjelasan guru, banyak siswa tidak mencatat, dan sangat jarang siswa bertanya. Dalam kondisi seperti ini, tidak akan terjadi pemrosesan informasi dalam otak siswa. Lebih lanjut, Zamroni (2001:1) menyatakan bahwa dewasa ini pendidikan cenderung menjadi sarana stratifikasi sosial dan sistem persekolahan yang hanya mentransfer kepada peserta didik apa yang disebut sebagai the dead knowledge, yaitu pengetahuan yang terlalu bersifat teksbookish, sehingga bagaikan sudah diceraikan dari akar sumbernya dan aplikasinya. Dengan kata lain, pembelajaran di sekolah menjadi tidak bermakna bagi siswa dan bermuara pada rendahnya prestasi belajar siswa.

Melihat kenyataan seperti ini, tampaknya perlu dilakukan reformasi pendidikan ke arah yang lebih baik. Reformasi tersebut perlu difokuskan pada: perubahan proses belajar-bukan sekedar-perubahan kurikulum, perubahan dari sistem pembelajaran yang mengutamakan mengingat dan menghafal ke arah pemahaman secara mendalam, perubahan proses yang cenderung memberi tahu ke arah pembelajaran yang mencari, mengolah, dan menemukan sendiri (inquiry), perubahan dari proses pembelajaran dari guru aktif ke siswa aktif, perubahan dari tanggung jawab guru menuju pada tanggung jawab siswa terhadap hasil belajarnya sendiri, serta dari penilaian yang berdasarkan paper and pencil test menuju pada penilaian yang sebenarnya (authentic assessment) (Suastra, 2006). Dalam rangka menyikapi permasalahan pembelajaran dan pengimlementasian pendidikan karakter pada pembelajaran, para guru sebagai pelaku utama dalam implementasi kurikulum di sekolah perlu merancang rencana pelaksanaan pembelajaran (RPP) agar sesuai dengan tujuan pendidikan. Landasan penyusunan RPP adalah Standar Proses Pendidikan. 
Keadaan yang terjadi pada kalangan guru di Bali belum seperti harapan yang dicanangkan. Sebagian besar RPP para guru belum memenuhi standar yang ditetapkan. Sering juga mereka membuat RPP hanya sebatas 'asal buat' untuk kelengkapan administrasi belaka. Padahal, RPP adalah tonggak awal untuk menghasilkan pembelajaran yang bermutu. Sesuai dengan prosedur standar seorang akademik, maka membuat perencanaan pembelajaran adalah langkah permulaan yang menentukan langkah-langkah berikutnya.

Menilik kondisi pendidikan dan juga harapan dari pembina pendidikan di wilayah ini, maka penyuluhan, terlebih lagi pelatihan dan pendampingan yang mengarah kepada usaha peningkatan kualitas pembelajaran berupa persiapan awal pembelajaran (RPP) sangat tepat untuk dilaksanakan. Tujuan kegiatan ini adalah memberikan bekal kepada guru-guru di SD Nomor 1 Kapal dalam menyusun RPP bermuatan pendidikan karakter sesuai harapan dari Standar Proses Pendidikan.

\section{Metode Pelaksanaan Pengabdian}

Untuk mencapai tujuan yang disebutkan di atas, kegiatan ini menggunakan model pelatihan disertai pendampingan untuk menangani permasalahan yang dihadapi. Kegiatan ini dilaksanakan di SD nomor 1 Kapal, dengan pesertanya adalah guru-guru yang mengajar di sekolah tersebut sebanyak 13 orang, dengan rincian 10 orang guru PNS, dan 3 orang guru honorer.

Secara sederhana, pelaksanaan kegiatan ini dapat uraikan sebagai berikut. Pertama, mereka diberikan terlebih dahulu pemahaman pentingnya menyusun RPP dalam kerangka pelaskanaan kurikulum dan juga pemahaman tentang pendidikan karakter dan dilanjutkan dengan tanya jawab terkait dengan seluk beluk penyusunan RPP yang bermuatan pendidikan kartakter. Sesi Kedua, peserta diajak praktik membuat rencana pembelajaran atau RPP. Dalam kegiatan ini, peserta diajak berlatih membuat RPP tahap demi tahap. Pada saat menyusun RPP dilakukan pendampingan oleh instruktur. Setelah itu, pada tahap ketiga, mereka mengimplementasikan RPP yang dibuat pada pembelajaran di kelas. Setelah itu mereka diajak melakukan refleksi tentang kegiatan yang telah dilakukan. Evaluasi dalam pelatihan ini menggunakan model evaluasi dalam proses dan produk. Evaluasi proses berupa observasi selama kegiatan pelatihan. 
Sementara untuk evaluasi produk, berupa penilaian terhadap unjuk kerja peserta berupa RPP yang telah dibuat. Untuk penilaian produk RPP menggunakan format penilaian yang digunakan dalam penilaian RPP untuk sertifikasi guru.

Kegiatan ini memiliki keterkaitan dengan lembaga formal yang menangani masalah kependidikan. Untuk tingkat dasar dan menengah, penanganan masalah pendidikan secara formal adalah wewenang dan tanggung jawab Departemen Pendidikan Nasional, yang dalam hal ini UPT terkait dan Diknas tingkat Kabupaten Badung, kepala sekolah, dan pengawas. Selain instansi tersebut, Universitas Pendidikan Ganesha (Undiksha) Singaraja juga merupakan lembaga yang terkait dengan kegiatan ini. Bantuan dari lembaga ini akan memuluskan jalannya kegiatan ini.

\section{Hasil dan Pembahasan}

Pelatihan ini dilaksanakan pada hari Sabtu, 12 Oktoberr 2013 sampai dengan 3 November 2013. Tempat pelatihan ini dilaksanakan adalah di SD No. 1 Kapal. Secara rinci, tempat pelatihan dapat disebutkan sebagai berikut (1) untuk pelatihan dan pendampingan penyusunan RPP dilaksanakan di Perpustakaan SD No 1 Kapal, (2) pendampingan dalam implementasi RPP dilaksanakan di kelas tempat guru tersebut mengajar. Pelaksanaan pelatihan ini diikuti oleh 13 orang guru. Pada sesi pertama, kegiatannya berupa pembukaan berlangsung dari pukul 08.00 Wita sampai pukul 08.30 Wita. Pembukaan pelatihan diisi pengarahan singkat dari Kepala Sekolah SD Nomor 1 Kapal. Setelah pembukaan, kegiatan pelatihan dilanjutkan dengan pemaparan tentang pendidikan karakter dilanjutkan dengan pemaparan tentang konsep penyusunan RPP sesuai dengan Standar Proses Pendidikan (Permendikbuk). Penjelasan dimulai dengan pentingnya RPP dalam pembelajaran, substansi yang seharusnya tertuang dalam RPP, prosedur penyusunan RPP, dan format penilaian RPP yang digunakan sekarang. Pada penjelasan tentang substansi RPP juga dijelaskan keberadaan ekslporasi, elaborasi, dan konfirmasi. Setelah itu dilanjutkan dengan hakikat pendidikan karakter yang sekarang ini diharuskan dimuatkan dalam RPP buatan guru.

Pada sesi ini, tampaknya peserta cukup antusias mengikuti pemaparan materi ini. Hal ini tampak dari pertanyaan yang muncul dari peserta dan juga keaktifannya selama penjelasan. Ada beberapa pertanyaan yang muncul diantaranya berikut ini. Seperti anggapan RPP hanya untuk kelengkapan administrasi bagi seorang guru, karena ketika 
mengajar di kelas, biasanya guru akan bebas berimprovisasi. Pertanyaan ini tampaknya cukup serius. Buktinya banyak guru yang setuju dengan ungkapan itu. Para guru mengatakan mereka justru merasa terkungkung dengan adanya RPP. Kreatifitasnya juga dipasung. Pendapat guru yang demikian tentu merupakan angin segar untuk menjelaskan lebih jauh tentang hakikat dan pentingnya RPP. RPP adalah langkah awal untuk memulai pembelajaran yang terarah karena di dalam RPP tercantum indikator maupun tujuan pembelajaran. Mengajar tentu saja harus memiliki arah yang jelas. Tanpa arah maka besar kemungkinan pelaksanaan pembelajaran akan berjalan sekehendak hati. Ada guru yang suka dengan topik tertentu dalam mata pelajarannya maka setiap mengajar dia akan mengajar topik yang disukainya saja. RPP mencegah hal seperti ini. RPP tidaklah memasung kreatifitas guru, kreatifitas guru sebaiknya sudah terlihat dari RPP yang disusun. Misalnya bagaimana merencanakan pelaksanaan pembelajaran yang inovatif dan kreatif, tentu dapat dituangkan dalam butir pelaksanaan pembelajaran mulai dari kegiatan pembuka, inti, sampai pada penutup.

Pertanyaan lain yang juga muncul adalah komponen yang harus ada dalam RPP dan bagaimana susunannya yang benar? Apakah perlu lagi komponen tujuan pembelajaran kalau sudah ada indikator? Untuk pertanyaan ini kembali dijelaskan tentang komponen RPP sesuai dengan Standar Proses Pendidikan (Permendikbud 41 tahun 2007 maupun 65 tahun 2013. Secara jelas pada Permen itu sudah tercantum komponen RPP, yaitu (1) iIdentitas mata pelajaran, (2) standar kompetensi atau kompetensi inti untuk Kurikulum 2013, (3) kompetensi dasar, (4) indikator pencapaian kompetensi, (5) tujuan pembelajaran, (6) materi ajar, (7) alokasi waktu, (8) metode pembelajaran, (9) kegiatan pembelajaran, yang mencakup kegitan pendahuluan, inti, penutup, (10) penilaian hasil belajar, (11) sumber belajar.

Dengan keberadaan tujuan pada Permendikbud tersebut, maka tujuan pembelajaran wajib ada dalam RPP. Namun, penjelasan tentang komponen RPP di atas kembali mengundang pertanyaan dari guru. Banyak guru yang masih belum paham dan juga bingung dengan istilah eksplorasi, elaborasi, dan konfirmasi. Padahal, tiga hal ini dituntut keberadaannya secara eksplisit oleh Permendikbud. Untuk itu, dikemukakan kembali penjelasan tentang ketiga hal tersebut. Pemaparan yang berlangsung masih banyak mendatangkan pertanyaan. Misalnya pertanyaan tentang keberadaan model 
pembelajaran sesuai Permendikbud 41 tahun 2007 dan Permendikbud Nomor 65 Tahun 2013. Dalam hal ini narasumber menyampaikan bahwa dalam kegiatan pembelajaran di RPP menurut Permen 41 tahun 2007 harus mencantumkan model/metode/ pendekatan/strategi. Dalam Kurikulum 2013, model pembelajaran yang disarankan adalah pendekatan saintifik. Nara sumber juga menekankan perbedaan antara alat, media, dan sumber belajar.

Diskusi kemudian berlanjut ke prosedur pembuatan RPP. Pada diskusi ini tampak muncul beberapa pertanyaan. Misalnya keberadaan materi pembelajaran. Apakah cukup dibuat judul-judulnya. Untuk ini, penyaji menjelaskan indikator penilaian RPP untuk sertifikasi guru. Kalau merperhatikan rambu-rambu penilaian RPP, maka materi pembelajaran dalam RPP perlu terlihat sistematikanya, keruntutannya, dan kesesuaiannya dengan alokasi waktu yang ada. Materi pelajaran cukup dibuat poinponnya saja, apalagi jika menggunakan Kurikulum 2013. Pada Kurikulum 2013 sudah ada buku siswa dan buku guru yang berikan materi yang lengkap dan juga prosedur pembelajarannya. Jawaban ini cukup memuaskan peserta.

Ketika praktik penyusunan RPP, kembali muncul beberapa pertanyaan, seperti tentang evaluasi. Namun secara umum, praktik berjalan dengan lancar. Para guru dapat menyusun RPP dengan lancar karena memang sebelum pelaksanaan pelatihan sudah diberitahukan agar mempersiapkan bahan untuk menyusun sebuah RPP. Setelah mereka selesai menyusun RPP, maka dilakukan "peer corection" terhadap RPP yang telah dibuat. Pedoman koreksi sejawat ini adalah pedoman yang digunakan dalam penilaian RPP pada sertifikasi guru.

Dari praktik menyusun RPP ini dihasilkan 11 RPP. Dari kesebelas RPP tersebut rata-rata skor yang didapat setelah dinilai berdasarkan pedoman penilaian RPP dengan $\Sigma \mathrm{N}=40$ adalah seperti tabel berikut.

Tabel 1. Pedoman Penilaian

\begin{tabular}{|l|l|l|}
\hline NO & \multicolumn{1}{|c|}{ ASPEK YANG DINILAI } & Rata-rata \\
\hline 1 & $\begin{array}{l}\text { Kejelasan perumusan tujuan pembelajaran (tidak } \\
\text { menimbulkan penafsiran ganda dan mengandung perilaku } \\
\text { hasil belajar) }\end{array}$ & 4 \\
\hline 2 & $\begin{array}{l}\text { Pemilihan materi ajar (sesuai dengan tujuan dan } \\
\text { karakteristik peserta didik) }\end{array}$ & 4,4 \\
\hline
\end{tabular}




\begin{tabular}{|l|l|l|}
\hline 3 & $\begin{array}{l}\text { Pengorganisasian materi ajar (keruntutan, sistematika } \\
\text { materi, dan kesesuaian dengan alokasi waktu) }\end{array}$ & 4,1 \\
\hline 4 & $\begin{array}{l}\text { Pemilihan sumber/media pembelajaran (sesuai dengan } \\
\text { tujuan, materi, dan karakteristik peserta didik) }\end{array}$ & 3,7 \\
\hline 5 & $\begin{array}{l}\text { Kejelasan skenario pembelajaran (langkah-langkah } \\
\text { pembelajaran : awal, inti, penutup) }\end{array}$ & 4,1 \\
\hline 6 & $\begin{array}{l}\text { Kerincian skenario pembelajaran (setiap langkah } \\
\text { tercermin strategi/metode dan alokasi waktu pada setiap } \\
\text { tahap) }\end{array}$ & 4 \\
\hline 7 & Kesesuaian teknik dengan tujuan pembelajaran & 4,1 \\
\hline 8 & Kelengkapan instrumen (soal, kunci, pedoman penskoran & 4,1 \\
\hline \multicolumn{2}{|c|}{ Skor Total } & $\mathbf{3 2 , 5}$ \\
\hline
\end{tabular}

Rata-rata sebesar 32,5 menunjukkan bahwa rata-rata tingkat keterampilan guru menyusun RPP bermuatan karakter adalah 81 pada skala 100. Nilai ini tentu perlu ditingkatkan lagi. Ada beberapa hal yang patut dibahas dari hasil pelatihan yang telah dilaksanakan. Pertama berkaitan dengan antusias guru untuk mengikuti pelatihan ini. Keantusiasan ini tentu saja sesuatu yang dapat kita sebut sebagai fantastis, walaupun pelaksana agak curiga juga apakah mereka benar-benar ingin mencari ilmu atau sekadar untuk mendapatkan sertifikat pelatihan. Kecurigaan itu akhirnya sirna karena setelah pelatihan berlangsung ternyata para guru cukup antusias mengikutinya. Tidak ada guru yang minta ijin tidak masuk apalagi bolos.

Motivasi yang tinggi dari guru saat mengikuti pelatihan ini tampaknya menjadi sebuah temuan yang pantas untuk dibahas. Mengapa guru begitu antusias dan memiliki motivasi yang tinggi? Hal ini tampaknya didorong oleh beberapa hal. Pertama, mungkin pelatihan yang mengarah kepada keterampilan semacam ini sangat jarang dilakukan. Jika benar demikian, maka ini membuktikan bahwa guru kita bukanlah sosok yang pasif dan ortodok yang selama ini sering terdengar. Mereka bukannya tidak senang dengan perubahan yang inovatif hanya mungkin strategi yang kita gunakan perlu dipikirkan. Model pengajaran anak kecil (pedagogi) jelas sangat tidak cocok dengan mereka yang sudah pada tua-tua. Oleh karena itu, pelatih yang akan memberikan bekal kepada para guru seharusnya paham dengan andragogi (pengajaran untuk orang dewasa). Dari minat dan motivasi yang diperlihatkan tampaknya para guru juga merupakan sosok yang gelisah mencari pengetahuan dan keterampilan baru. Rasa ingin tahu dan keinginan untuk berkembang yang tinggi dari guru sangat tampak. Hal ini sebenarnya merupakan 
potensi yang sangat mungkin dikembangkan menjadi sesuatu yang berhasil guna. Kalau ada yang mengatakan bahwa guru kurang aktif, loyo, malas dan lain-lainnya, tampaknya tidaklah selalu benar. Mereka selalu ingin berkembang. Mereka juga ingin menghasilkan sesuatu yang fundamental. Mereka menjadi kurang aktif karena kurangnya rangsangan untuk berkarya secara nyata, kurangnya kepraktisan dalam pelaksanaan tugas-tugasnya. Mungkin cara-cara pelatihan, penataran dan sebagainya yang selama ini lebih banyak menanamkan pemahaman terhadap teori yang verbalistik, tanpa adanya realisasi dalam kehidupan guru di sekolah. Kedua, guru tampaknya merasa bahwa segala yang mereka dapatkan dalam pelatihan ini bermanfaat langsung untuk kehidupannya profesinya. Ini berarti prinsip kebermaknaan dan keterkaitan sangat menopang antusias dan motivasi guru untuk mengikuti kegiatan sejenis ini.

Pelatihan ini yang meruapakan salah satu bentuk pembelajaran ini perlu dibuat sealamiah mungkin sehingga mereka merasakan kebermaknaan dan kepraktisannya. Guru akan senang jika mereka langsung dapat melihat hasil karyanya. Ini adalah teori yang sudah cukup lama, tetapi sering dilupakan dalam pembelajaran. Dalam pelatihan ini, kebenaran konsep ini tampaknya muncul. Dengan langsung dapat melihat hasil kerjanya berupa RPP, dan perangkat pembelajaran lainnya, tampak lebih menantang dan menggairahkan mereka lebih giat meningkatkan pengetahuan dan keterampilannya atau keprofesionalannya. Dari rata-rata kemampuan guru sebesar 32,5 atau 81pada skala 100, dapat dijelaskan bahwa nilai tersebut masih dapat ditingkatkan lagi. Alasannya, jika perencanaan pembelajaran belum maksimal maka dapat diduga pelaksanaan pembelajaran tidak akan berjalan dengan baik.

\section{Penutup}

Dari pelaksanaan pelatihan ini, dapat disimpulkan hal-hal sebagai berikut. (1) Rata-rata skor yang diperoleh oleh guru SD N 1 Kapal dalam penyusunan RPP bermuatan karakter adalah 32,5. Skor ini setara dengan nilai 81 pada skala 100, (2) Sebagaian besar guru, khususnya peserta pelatihan sangat memerlukan adanya pelatihan semacam ini. Hal ini dapat dilihat dari keantusiasan mereka saat mengikuti pelatihan. Mereka sangat menikmati pelatihan ini sehingga semua tugas yang diberikan dikerjakan dengan motivasi yang tinggi, (3) Sebagian besar guru yang menjadi peserta pelatihan membawa pengetahuan awal mengenai pelatihan sebagai sesuatu yang hanya sekadar 
formalitas belaka dan verbalistik sehingga tidak dapat diterapkan secara nyata dalam kesehariannya sebagai guru, (4) Pelaksanaan pelatihan dapat meningkatkan kemampuan para peserta dalam hal menyusun rencana pelaksanaan pembelajaran (RPP) yang sesuai Kurikulum (KTSP dan Kurikulum 2013) , (5) Pelaksanaan pelatihan juga dapat meningkatkan apresiasi guru tentang pentingnya teori-teori baru untuk meningkatkan kualitas pembelajaranan yang dilaksanakan di sekolahnya.

\section{DAFTAR PUSTAKA}

Depdiknas. 2006. Penjelasan Instrumen Penilaian Kinerja Guru 1 (Kemampuan Merencanakan Pembelajaran). Jakarta: Direktorat Profesi Pendidik, Dirjen Peningkatan Mutu Pendidik dan Tenaga kependidikan dan Direktorat Ketenagaan Dirjen Dikti.

Dit PSMP Kemdiknas. 2010. Pendidikan Karakter Terintegrasi dalam Pembelajaran di Sekolah Menengah Pertama. Jakarta: Direktorat PSMP Kemdiknas.

Djoko Sasongko. 2010. Pendidikan Karakter dan Budaya Bangsa dalam Rangka Membangun Peradaban Manusia. Makalah disampaikan dalam Kegiatan Workshop Pendidikan Karakter dan Budaya Bangsa pada tanggal 30 Mei s.d 2 Juni 2010 .

Doni Koesoema A. 2007. Pendidikan Karakter: Strategi Mendidik Anak di Zaman Global. Jakarta: Grasindo. Cet. I.

Kemdiknas. 2010. Desain Induk Pendidikan Karakter. Jakarta: Kementerian Pendidikan Nasional.

Kementrian Pendidikan dan Kebudayaan. 2012. Dokumen Kurikulum 2013 Jakarta : Kementerian Pendidikan dan Kebudayaan.

Kementrian Pendidikan dan Kebudayaan. 2013. Kurikulum 2013 : Kompetensi Dasar Sekolah Dasar (SD)/Madrasah Ibtidaiyah (MI). Jakarta : Kementerian Pendidikan dan Kebudayaan

Lickona, Thomas. 1991. Educating for Character: How Our School Can Teach Respect and Responsibility. New York, Toronto, London, Sydney, Aucland: Bantam books.

Munir, Abdullah. 2010. Pendidikan Karakter Membangun Karakter Anak Sejak dari Rumah. Yogyakarta: Pedagogia. 
Nucci, Larry P. dan Narvaez, Darcia. 2008. Handbook of Moral and Character Education. Routledge taylor \& francis group. New York and London.

Pemerintah Republik Indonesia. 2010. Kebijakan Nasional Pembangunan Karakter Bangsa Tahun 2010-2025. Jakarta: Pusat Kurikulum Balitbang Kemdiknas.

Peraturan Menteri Pendidikan Nasional Republik Indonesia Nomor 41 Tahun 2007 tentang Standar Proses untuk Satuan Pendidikan Dasar dan Menengah.

Peraturan Menteri Pendidikan Nasional Republik Indonesia Nomor 65 Tahun 2013 tentang Standar Proses untuk Satuan Pendidikan Dasar dan Menengah

Peraturan Pemerintah No. 19 Tahun 2005 tentang Standar Nasional Pendidikan.

Pusat Kurikulum Balitbang Kementerian Pendidikan Nasional. 2010. Pengembangan Pendidikan Budaya dan Karakter Bangsa, Pedoman Sekolah.

Pusat Kurikulum Kemdiknas. 2009. Pengembangan dan Pendidikan Budaya dan Karakter Bangsa: Pedoman Sekolah. Jakarta: Pusat Kurikulum Balitbang Kemdiknas.

Suastra, I,W. 2006. Peningkatan Kualitas Proses dan Hasil Belajar Siswa Melalui Pembelajaran Inovatif. Makalah Disajikan pada Pelatihan "Pakem" bagi Guruguru di Kabupaten Bangli. Tanggal 4 s.d 22 Desember 2006.

Suastra, I.W. 2006. Pengembangan Sistem Asesmen Otentik dalam Pembelajaran Fisika di SMA. Hasil Penelitian. Tidak Dipublikasikan.

Undang-undang Republik Indonesia Nomor 20 Tahun 2003 tentang Sistem Pendidikan Nasional. 